\title{
気流層石炭ガス化装置における飛出しチャーの 加圧ガス化反応特性
}

\author{
- 1997.9.12 受理一
}

\author{
北海道工業技術研究所*1 本間 専治, 武田 詔平, 北野 邦尋 \\ 吉田 諒一 \\ 株式会社 日立製作所*2 小山俊太郎 \\ バブコック日立株式会社*3 植田 昭雄
}

\section{1. 緒 言}

気流層石炭ガス化炉では，炉上部から微粒子がガス に同伴されて飛び出す。この飛出し粒子は, 通常未反 応炭素を含んでいるので, 炭素転換効率を高めるには サイクロンで捕集してガス化炉へリサイクルする方法 が提言されている。飛出し粒子に関しては，その飛出 し量に及ぼすガス化反応温度, 圧力, ガス流速などの

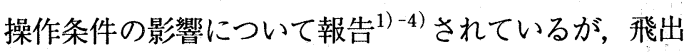
しチャー粒子のガス化反応性については明らかにされ ていない。これまでの知見から, 飛出しチャ一は高温 場で熱履歴を受けているため反応性が悪いと推測され, リサイクルによりガス化炉内に供給した場合, 未反応 炭素が系内に集積して運転の障害になることが懸念さ れる。チャーのガス化反応は, 燃焼や熱分解反応に比 べて遅いので，実プロセスの開発を効率的に進めるた めに高温加圧下で検討することが重要である。

石炭のガス化反応性に関し, 微粉の石炭を高温でガ ス化する気流層型のガス化炉では, 物質移動が律速と なり炭種の差による影響は少ないものと近年まで考え られてきた。しかし，1273～2073 K の温度条件で反 応速度を調べた笠岡ら ${ }^{5)}$, 小山ら ${ }^{6)} や$ Wells $ら^{7)}$ によ る結果では, 炭種により異なることが明らかになって いる。また, 武田ら ${ }^{8) 9}$ は反応速度に関し圧力効果が 認められることを報告しているが, $1273 \mathrm{~K}$ 以上の高 温条件下での研究は行われていない。

*1 札幌市豊平区月寒東 $2-17$

*2 日立研究所 茨城県勝田市堀口 832-2

*3 点研究所広島県豊田郡安芸津町風早 3300
本研究では, 3 ton/day 二段気流層ガス化装置のサ イクロンで捕集された 4 炭種からの飛出しチャー粒子 および比較のために回分式装置を用いて製造した乾留 チャーについて, 高温加圧下 (温度1073 1573 K, 圧 力0.4〜3.1 MPa）における炭酸ガスによるガス化反 応性を検討した。さらに, 昇温脱離法によるチャー粒 子表面の活性点の測定を行い, 炭種による飛出し チャーのガス化反応性について考察を行った。

\section{2. 実 験}

\section{1 原料およびチャー試料}

使用した 4 種類の原料石炭の工業分析值および元素 分析值を Table 1 に示す。実験には, これら原料石 炭を 3 ton/day 二段気流層ガス化装置によりガス化し サイクロンで捕集したチャーおよび比較のために回分 式装置により乾留したチャーを使用した。前者の チャー試料は, 粒径 $74 \mu \mathrm{m}$ 以下に調整した原料石炭 を下段ガス化反応温度 $1780 \mathrm{~K}$, 上段温度 $1370 \mathrm{~K}$, 圧力 $0.4 \mathrm{MPa}$ の条件で, ガス化剤には酸素と窒素の混合ガ スを使用してガス化したときに炬上部から排出する飛 出し粒子（CY チャー）である。後者のチャー試料は, JIS 法に従い粒径 $250 \mu \mathrm{m}$ 以下に調整した原料石炭を 石英製反応管 $(43 \mathrm{~mm} \phi \times 550 \mathrm{~mm})$ に約 $50 \mathrm{~g}$ 充填し た後, アルゴンガスを約 $100 \mathrm{~m} \ell / \mathrm{min}$ 流しながら 10 $\mathrm{K} / \mathrm{min}$ で昇温し, 所定の温度 $(1273 \mathrm{~K})$ に到達後 1 時間保持して急冷したもの（乾留チャー）である。な お, 前述した $74 \mu \mathrm{m}$ 以下の原料石炭についても同様 に乾留したチャーを作り比較検討を行った。これら 
Table 1 Properties of parent coals used

\begin{tabular}{|c|c|c|c|c|c|c|c|c|c|}
\hline \multirow[t]{2}{*}{ Samples } & \multicolumn{4}{|c|}{$\begin{array}{c}\text { Proximate analyses } \\
\text { wt } \%\end{array}$} & \multicolumn{5}{|c|}{$\begin{array}{l}\text { Ultimate analyses } \\
\text { d. a. f. wt } \%\end{array}$} \\
\hline & Mois. & Ash & V. M. & F. C. & C & $\mathrm{H}$ & $\mathrm{N}$ & $\mathrm{O}$ & S \\
\hline Taiheiyo & 5.0 & 10.5 & 43.9 & 40.6 & 76.5 & 6.2 & 1.2 & 15.2 & 0.4 \\
\hline Ebenezer & 3.4 & 12.3 & 38.5 & 45.8 & 79.8 & 6.0 & 1.1 & 12.5 & 0.5 \\
\hline Massel Buluck & 3.4 & 11.8 & 35.5 & 49.3 & 80.2 & 5.1 & 1.1 & 12.0 & 1.1 \\
\hline Datong & 7.0 & 8.5 & 29.5 & 55.0 & 84.4 & 4.4 & 0.4 & 10.8 & 0.3 \\
\hline
\end{tabular}

Ebenezer, Massel Buluck; Australia, Datong; China

Table 2 Properties of Various chars

\begin{tabular}{|c|c|c|c|c|c|c|c|c|c|c|}
\hline \multirow[t]{2}{*}{ Samples } & \multicolumn{4}{|c|}{$\begin{array}{c}\text { Proximate analyses } \\
\text { wt } \%\end{array}$} & \multicolumn{6}{|c|}{$\begin{array}{l}\text { Ultimate analyses } \\
\text { d. b. wt } \%\end{array}$} \\
\hline & Mois. & Ash & V. M. & F. C. & $\mathrm{C}$ & $\mathrm{H}$ & $\mathrm{N}$ & $\mathrm{O}$ & S & ash \\
\hline Taiheiyo CY char & 2.4 & 45.6 & 3.6 & 48.4 & 50.5 & 0.3 & 0.2 & 1.8 & 0.4 & 46.7 \\
\hline char & 3.6 & 22.5 & 1.5 & 72.4 & 75.7 & 0 & 0.4 & 0.5 & 0.3 & 23.3 \\
\hline Ebenezer CY char & 1.4 & 46.4 & 3.7 & 48.5 & 51.3 & 0.1 & 0.2 & 1.9 & 0.4 & 47.0 \\
\hline " char & 1.5 & 20.9 & 0.8 & 76.8 & 77.0 & 0.8 & 0.2 & 0 & 0.3 & 21.3 \\
\hline Massel Buluck CY char & 2.6 & 36.0 & 2.5 & 58.9 & 61.4 & 0 & 0.3 & 1.3 & 1.2 & 37.0 \\
\hline " char & 2.3 & 21.5 & 0.9 & 75.3 & 77.6 & 0 & 0.5 & 0 & 1.7 & 22.0 \\
\hline Datong CY char & 1.8 & 31.2 & 1.7 & 65.3 & 64.3 & 0.1 & 0.1 & 1.0 & 0.3 & 31.8 \\
\hline char & 3.1 & 11.9 & 1.6 & 83.4 & 84.1 & 1.2 & 0.5 & 0 & 0.3 & 12.2 \\
\hline
\end{tabular}

CY char: Captured char by cyclone

char : Carbonized char at $1273 \mathrm{~K}$

チャー試料の工業分析值および元素分析值を Table 2 に示す。CY チャーは，乾留チャーに比べどの炭種に ついても炭素含有量が少なく, 灰分含有量が多い。こ れはCYチャー試料が部分的にガス化されていること によるものであり，そのガス化反応率 $\left(\mathrm{Xc}_{\mathrm{c}}\right)$ は $\left(\mathrm{Xc}=1-\left(\mathrm{C} / \mathrm{C}_{0}\right) \cdot\left(\mathrm{A}_{0} / \mathrm{A}\right) ;\right.$ ここで $\mathrm{C}_{0}$ 抢よび $\mathrm{C}$ は原

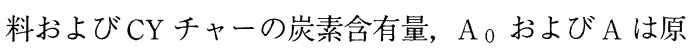
料およびCY チャーの灰分含有量) 0.71〜0.78であっ た。

\section{2 装置および実験方法}

チャーの炭酸ガスによるガス化反応実験には, 既 報 $^{8)}$ の上血型二塔式高温高圧熱天科 (耐熱温度, 圧力 ：1273 K, $10 \mathrm{MPa}$ ） $1580 \mathrm{~K}, 10 \mathrm{MPa}$ までの温度, 圧力下で測定できるように改造した電気炉を使用した。 その概略を Fig. 1 に示す。反応による重量変化は, トーション型零位法マイクロバランスによる電気変位 から求めた。また, 試料セルは, $8.0 \mathrm{~mm} \phi \times 2.5 \mathrm{~mm}$
のアルミナ製血型で，その底部は試料と反応ガスとの 接触を良好に保つためにアルミナ製多孔質フイルター とした。

実験操作は既報8)に準じて行った。すなわち，ガス 置換, 圧力調整を行った後昇温して, 所定の温度に達 した後，アルゴンガスから炭酸ガスに切り換えてガス 化反応を開始した。本実験装置によるガス化反応中の チャーの見掛け減量測定值は粒子外境膜内の物質移動 の影響を受ける。そこで, ガス線速度, 圧力, 試料重 量の影響について検討した結果，七ル近傍のガス線速 度を圧力にかかわらず $1.05 \mathrm{~cm} / \mathrm{sec}$ 一定とし, 試料充 填量は CY チャーの場合 $10 \mathrm{mg}$, 乾留チャーの場合 20 $\mathrm{mg}$ とすることにより, 再現性のよい減量曲線が得ら れることが判明した。

チャー粒子の表面状態は走査型電子顕微鏡（日本電 子製 T-330 A）により観察し，その表面積を BET 法, 見掛け密度を水銀置換法により測定した。昇温脱離法 による活性点の評価は，既報 ${ }^{10)}$ と同様に，石英製反 


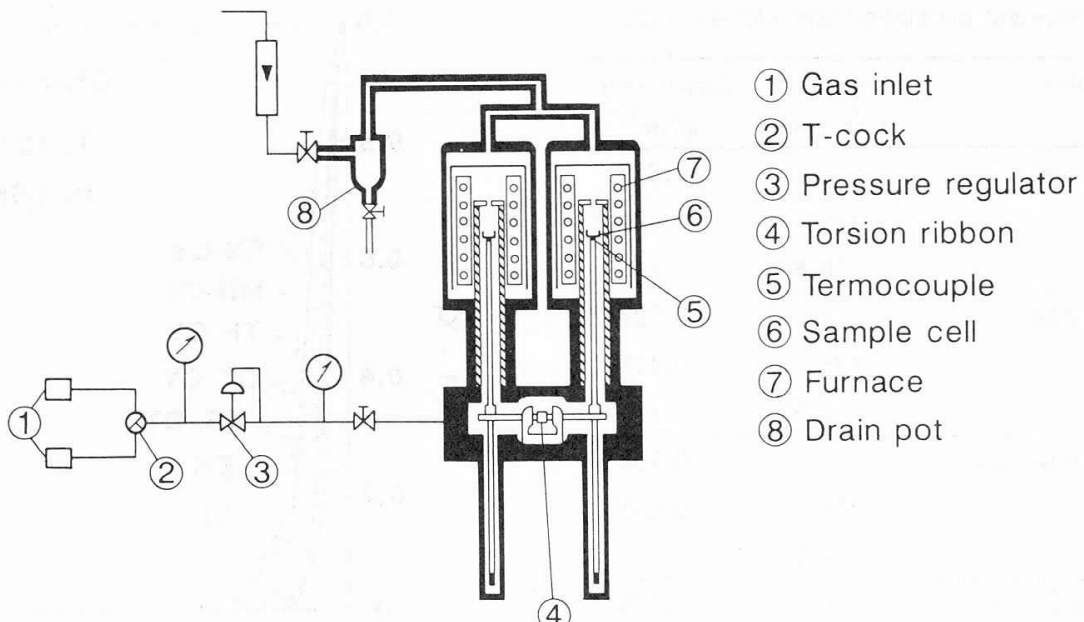

Fig. 1 Schematic diagram of high pressure TGA apparatus

応管の中央に約 $200 \mathrm{mg}$ の試料を充填した後，減圧， 加熱して試料表面に吸着した酸素を除去する。ついで, 所定量の炭酸ガスを吸着させた後, 一定速度で加熱し, 所定の温度に到達後これを保持して, 発生した脱離ガ スをガスクロマトグラムで定量分析した。

\section{3．実験結果および考察}

\section{1 チャー粒子性状}

CY チャー粒子および乾留チャーについて走査型電
子顕微鏡（SEM）により観察した結果を太平洋炭と エベネザ炭の場合について Fig. 2 に示す。図中, 左 側の CY チャーの表面は粗く，大小の穴が発達して拧 り，形状は角がなく丸みを带び球状の粒子も見られる。 これに対して，右側の乾留チャーは太平洋炭拉よび工 ベネザ炭のいずれの粒子も表面は比較的滑らかで角 ばっている。このような傾向は，マッセルブルックお よび大同炭チャ一粒子についても同様に観察された。

これらチャー粒子の単位チャー重量当たりの比表面

\section{Cyclone char}

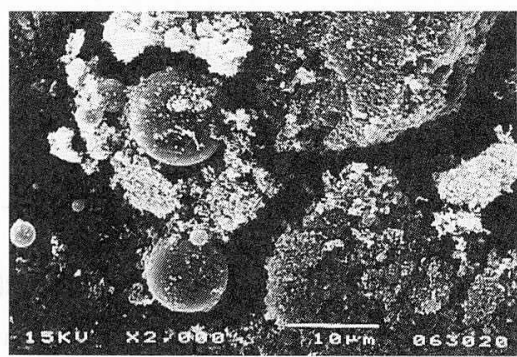

Ebenezer

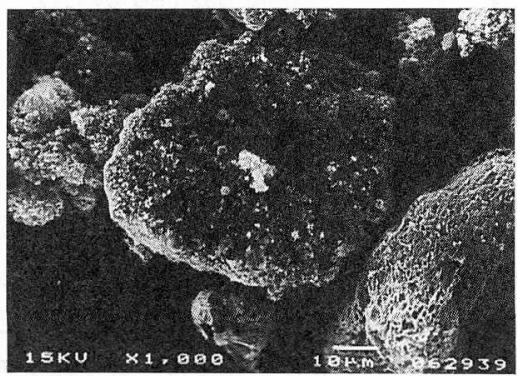

Char,H.T.T.1273K
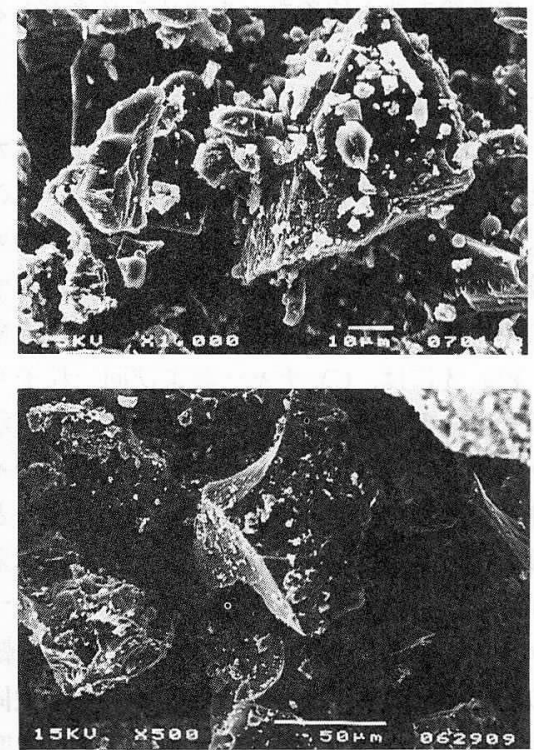

Fig. 2 SEM photographs for various chars 
Table 3 Surface area and apparent density for various chars

\begin{tabular}{lcc}
\hline \multicolumn{1}{c}{ Samples } & $\begin{array}{c}\text { Surface area } \\
\mathrm{m}^{2} / \mathrm{g} \text {-char }\end{array}$ & $\begin{array}{c}\text { Apparent density } \\
\mathrm{g} / \mathrm{cm}^{3}\end{array}$ \\
\hline Taiheiyo raw coal & - & 0.819 \\
cyclone char & 150 & 0.424 \\
$1273 \mathrm{~K}$ char & 10.8 & - \\
\hline Ebenezer raw coal & - & 0.727 \\
cyclone char & 125 & 0.417 \\
$1273 \mathrm{~K}$ char & 3.8 & - \\
\hline Massel Bluck raw coal & - & 0.753 \\
cyclone char & 154 & 0.455 \\
$1273 \mathrm{~K}$ char & 2.8 & - \\
\hdashline Datong raw coal & - & 0.684 \\
cyclone char & 167 & 0.412 \\
$1273 \mathrm{~K}$ char & 6.9 & - \\
\hline
\end{tabular}

積と見掛け密度を測定した結果を Table 3 に示す。 CY チャーの比表面積はすでにガス化反応を受けてい るため, 乾留チャーに比べてどの炭種についても大き く, SEM で観察した粒子表面に穴が発達している様 子と良く対応している。また，粒径が異なる二種の乾 留チャーの比表面積は同程度であった。表中には, 原 料石炭とCY チャーの見掛け密度の值も示した。CY チャーの見掛け密度はどの炭種についても原料石炭よ り小さく，ガス化炉にリサイクルする場合にこの性状 を考慮して供給方法や位置などを決める必要がある。

\section{2 ガス化反応性}

$\mathrm{CY}$ チャーおよび乾留チャーを $\mathrm{CO}_{2}$ ガスによりガス 化したときのチャー中炭素の未反応率（1-X 汭で $\mathrm{X}$ は熱天科の重量変化から求められる炭素基準のガス 化反応率）と反応時間の関係を Figs. 3，4 に示す。 この場合のガス化条件は, 温度 $1573 \mathrm{~K}$, 圧力 $1.6 \mathrm{MPa}$ である。Fig. 3 には，CY チャーおよび同一粒子サイ ズの乾留チャーの見掛けガス化反応速度について示し た。図から明らかなように, CY チャーと乾留チャー の反応速度をそれぞれ同一炭種について比較すると， 前者は後者よりも大きい。CY チャーでは，エベネザ 炭（EN）が最も大きく, ついで太平洋 (TH), マッ セルブルック (MB), 大同炭 (DT) であり, 乾留 チャーの場合には太平洋>マッセルブルック>大同> エベネザの順であった。各 CY チャーの反応速度と Table 3 に示した比表面積には相関がみられない。そ

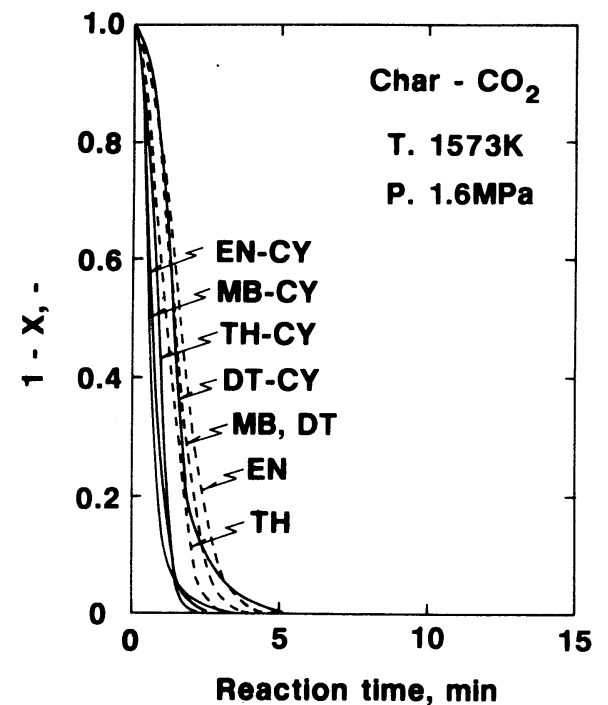

Fig. 3 Change of carbon conversion for cyclone chars and carbonized chars gasified by $\mathrm{CO}_{2}$

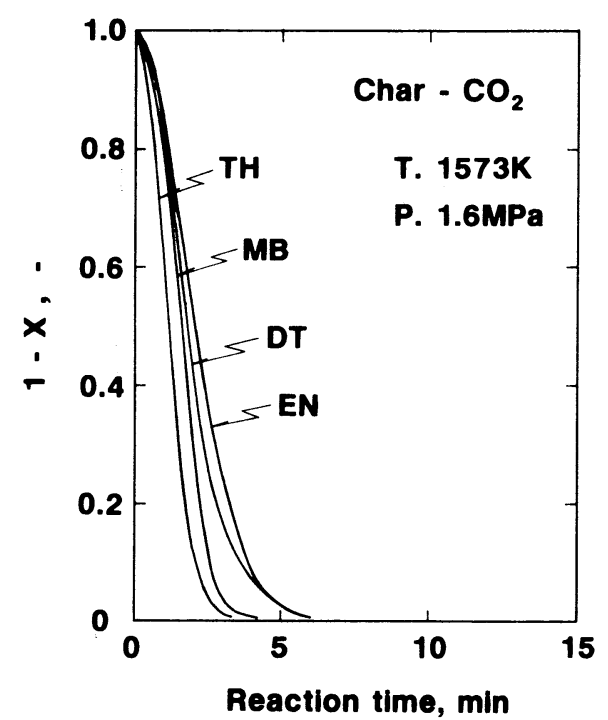

Fig. 4 Change of carbon conversion for carbonized chars gasified by $\mathrm{CO}_{2}$

こで，CYチャーはガス化が進んでいることを考慮し て, 表面積と反応性の相関を認めている知見 ${ }^{8) 11112) ~}$ から, 単位初期チャー重量当たり基準の比表面積と反 応速度の相関を求めたが，この場合についても両者に は明確な相関が認められなかった。一方， $-250 \mu \mathrm{m}$ の乾留チャーの結果（Fig. 4) についてみると，見掛 けガス化反応速度は，太平洋炭チャーが最も大きく, マッセルブルック，大同およびエベネザ炭チャーの順 
に小さくなっている。この結果と $-74 \mu \mathrm{m}$ の乾留 チャーを比較すると, 見掛け反応速度は後者の方が大 きく，粒子サイズの影響が認められるが，炭種による ガス化反応速度の順位は同じであった。これらの結果 については，後述する粒子表面の活性点から考察する。

Figs. 3，4 に拈いて，ガス化反応速度は炭素末反応 率の 1 次に比例すると仮定し, 時間に対して片対数プ ロットした場合に得られる反応初期 $(\mathrm{X}:$ ： 0.3）の 直線部の勾配から求めた見掛け初期反応速度と全圧と の関係を Fig. 5 に示す。反応温度が $1273 \mathrm{~K}$ の場合 (破線)，いずれの CY チャーおよび乾留チャーにつ いても傾きはほぼ $1 / 4$ であるが, $C Y$ チャーの中でガ ス化反応速度が最も大きいエベネザ炭チャー, 並びに 乾留チャーの中ではガス化反応速度が最も大きい太平 洋炭チャーについては, 圧力の影響がいくぶん小さい 傾向にある。一方，反応温度が $1573 \mathrm{~K}$ （実線）にお ける圧力の影響は，どのチャーについても $1273 \mathrm{~K} の$ 場合に比べて小さい。圧力依存性については，常圧下 で 1 次，分圧を変えた場合 $1 / 2$ 次あるいは $1 / 3$ 次,

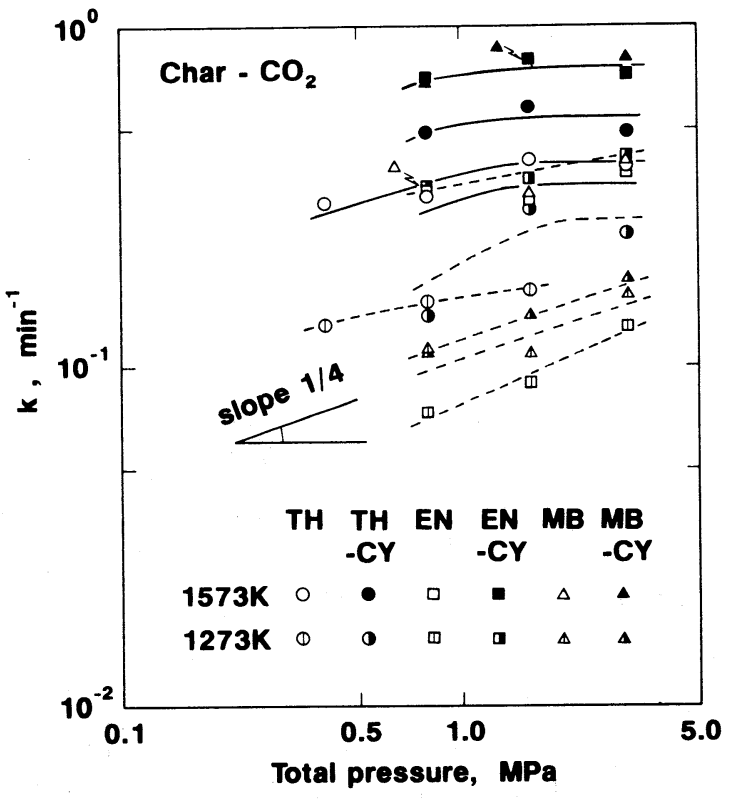

Fig. 5 Pressure effect on initial reaction rate constant for $\mathrm{CO}_{2}$ gasification

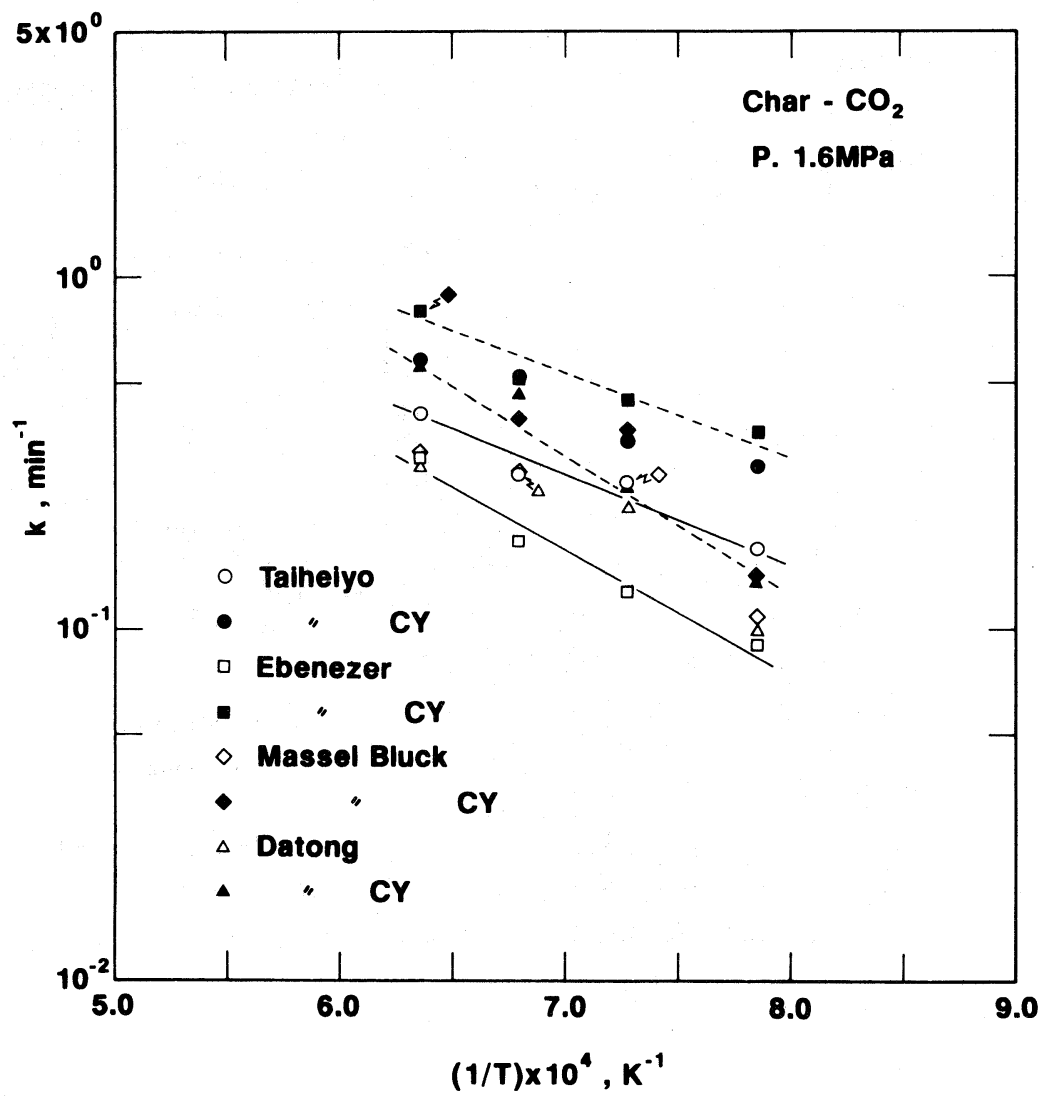

Fig. 6 Arrhenius plots on initial reaction rate constant for various chars 
1.6 MPa 以上では 0 次としている報告があり ${ }^{13)}{ }^{14)}$, 本実験結果から，ガス化反応速度に及ぼす圧力の影響 は， $1273 \mathrm{~K}$ の温度近傍では圧力のおよそ $1 / 4$ 乗に比 例し， $1573 \mathrm{~K}$ では1.6 MPa 以上で認められなくなる。

Fig. 6 には，反応温度 $1273 \sim 1573 \mathrm{~K}$, 圧力 $1.6 \mathrm{MPa}$ の場合の各 CY チャーおよび乾留チャーの初期反応速 度と反応温度との関係を示す。図から，CY チャーの 反応速度は乾留チャーに比べて高いものの, 同一オー ダーであることが分かる。Shemet ら ${ }^{15)}$ は1073 K 近傍 で反応律速から拡散律速へと律速過程が変化すること を述べており，直線の傾きから求められる活性化エネ ルギーの值もおよそ 50 ～ $80 \mathrm{~kJ} \cdot \mathrm{mol}^{-1}$ であるが， $\mathrm{CY}$ チャーの反応速度は乾留チャーに比べて高く, 炭種に よる反応速度の差も，このような高温下においてもな お認められた。

サイクロンで回収されたチャーは高温場の熱履歷を 受けているために反応性が低いと考えられていたが， 本結果から明らかなように，昇温速度が低く（10 $\mathrm{K} / \mathrm{min}$ ）長時間乾留したチャーに比べて，反応速度が 数倍大きいという結果が得られた。

\section{3 ガス化反応の定量的評価}

炭種によるガス化反応速度の違いは粒子表面の反応 活性点によって統一的に評価できると考えられてい

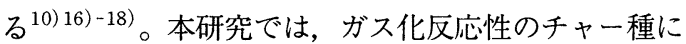
よる相違を考察するために，粒子表面の活性点の測定 を昇温脱離法（TPD 法）により行った。CY チャーに ついて得られた結果を Fig. 7 に示す。この図は, $\mathrm{CO}_{2}$ と CO ガスの脱離速度を, 昇温中の温度および保持温 度に達してからの時間に対してプロットしたものであ る。破線で示した $\mathrm{CO}_{2}$ の脱離は，エベネザ炭と大同炭 CY チャーの場合ほぼ1073 K までに終了している。一 方, 実線で示した CO の脱離は, $1073 \mathrm{~K}$ の保持温度 に達した後60分まで継続しており，中でもエべネザ炭 CY チャーの脱離ガス量は大きい。この実験では，吸 着した $\mathrm{CO}_{2}$ はそのまま脱着するか, チャー表面に酸素 を残して CO として脱着する。すなわち，ガス化反応 に寄与するのは，吸着した $\mathrm{CO}_{2}$ のうち，後者の $\mathrm{CO}$ と して脱離する $\mathrm{CO}_{2}$ と考えられるので，このような吸着 サイトをガス化活性点と定義して，チャー初期重量当 たりの活性点数は，図に示した $\mathrm{CO}$ の脱離速度曲線を 図積分して求めた。Fig. 8 には，CY チャーおよび $1273 \mathrm{~K}$ で乾留したチャーについて求めた活性点数と それら各チャーを $1273 \mathrm{~K}, 1.6 \mathrm{MPa}$ の条件でガス化し たときの初期反応速度との相関について示す。太平洋

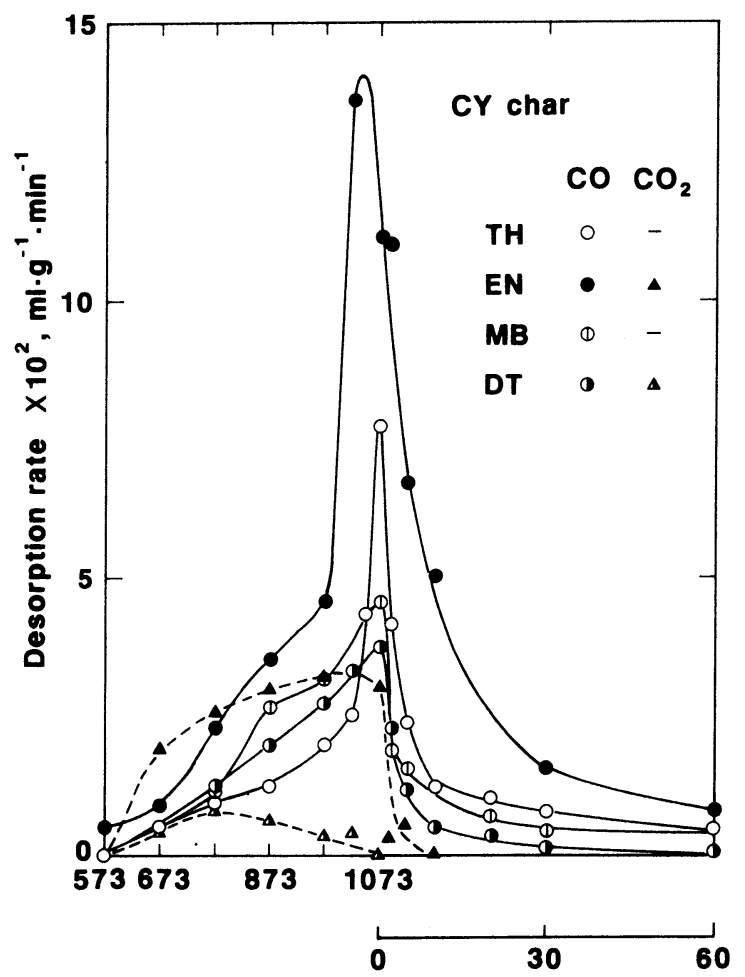

Temperature, $K \quad$ Holding time, $\min$

Fig. 7 Desorption rate of adsorbed $\mathrm{CO}_{2}$ from cyclone chars

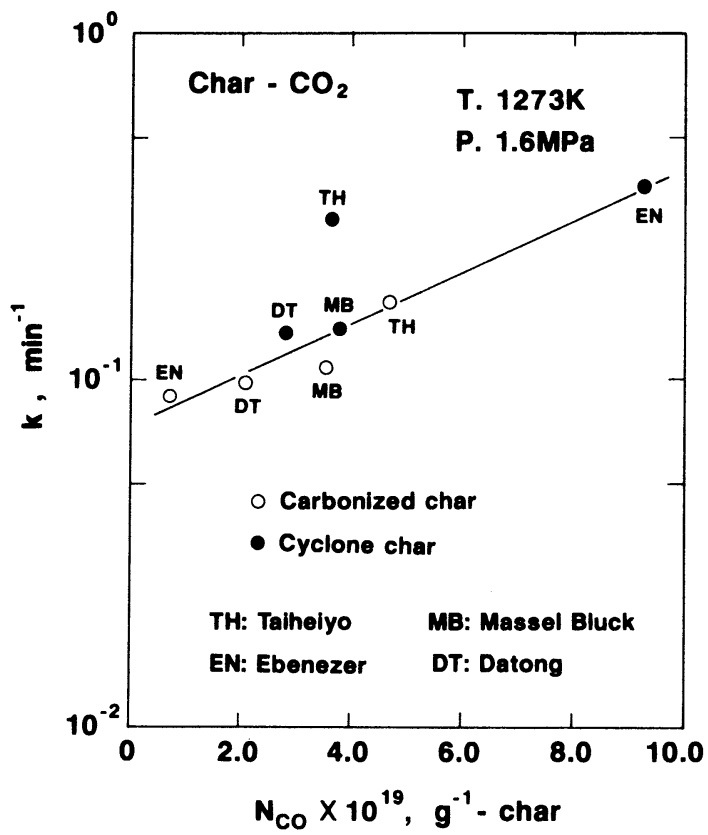

Fig. 8 Correlation of initial reaction rate constant with total number of active site 
炭 CY チャーの場合を除くと，チャー種によらず良好 な相関が得られている。橋本ら ${ }^{19)}$ は $1458 \mathrm{~K}$ でガス化 速度を測定し，比較的低品位の石炭においては含有鉱 物質による触媒作用の違いが炭種によるガス化速度に 反映するとしており，太平洋炭 CY チャーの特異性の 一つの原因と考えられる。このように熱履歴や炭種が 異なっていても反応速度の順位が活性点数で整理でき ることが示された。一般に, 高温においては反応の律 速過程が拡散過程に移行すると考えられているが, 本 実験結果に示すように $1273 \mathrm{~K}$ から $1573 \mathrm{~K}$ においても 反応の寄与が大きく活性点数による整理が有効なもの と考えられる。

\section{4. 結 言}

ガス化炉から飛出したサイクロン捕集チャーと乾留 チャーそれぞれ 4 種類について, 反応温度1273 1573 $\mathrm{K}$, 圧力 $0.4 \sim 3.1 \mathrm{MPa}$ の条件下で, ガス化反応速度 を比較検討した。その結果, 以下のことが明らかに なった。

1) 飛出しチャーおよび乾留チャーの炭種によるガス 化反応速度の違いは, チャー粒子の活性点数で統 一的に説明できる。

2) 見掛け初期反応速度の圧力依存性は, $1270 \mathrm{~K}$ の 温度域近傍では圧力のおよそ $1 / 4$ 乗に比例するが, $1570 \mathrm{~K}$ の高温域では炭種によらず $1.6 \mathrm{MPa}$ 以上 で認められなくなる。

3 ）チャーのガス化反応速度は $1273 \mathrm{~K} \sim 1573 \mathrm{~K}$ の高 温においても炭種により異なる。

4 ）気流層型ガス化炉からの飛出しチャーのガス化反 応速度は, 昇温速度が低く $(10 \mathrm{~K} / \mathrm{min})$ 長時間 乾留したチャーに比べて数倍大きい。

\section{文献}

1) 藤岡祐一, 石 栄愇, 化工論文集, 20, 774 (1994)

2 ) Kawabata, J., Yumiyama, M., Tazaki, Y., Honma, S., Takeda, S., Chiba, T. and Yoshida, K., J. Chem. Eng. Japan, 12, 389 (1979)

3 ) 本間専治, 田崎米四郎, 弓山 翠, 武田詔平, 北
野邦尋, 山口 弘, 河端淳一, 森 滋勝, 燃協誌, 61, 998(1982)

4 ) 武田詔平, 北野邦尋, 本間専治, 田崎米四郎, 弓 山 翠, 鶴江 孝, 千葉繁生, 河端淳一, 千葉忠 俊，燃協誌，69, 1068 (1990)

5 ）笠岡成光, 阪田祐作, 童楚 良, 燃協誌, 62, 335 (1983)

6 ) 小山俊太郎, 田中真二, 松尾光弘, 森原 淳, 野 北舜介, 燃協誌, 65, 746 (1986)

7 ) Wells, W.F. and Smoot, L.D., Fuel, 70, 455 (1991)

8 ) 武田詔平, 北野邦尋, 窪田純一, 河端淳一, 佐藤 春三, 石 栄煒, 千葉忠俊, 燃協誌, 64, 409 (1985)

9 ）武田詔平, 本間専治, 田崎米四郎, 弓山 禾, 北 野邦尋, 河端谆一, 千葉忠俊, 竹澤暢恒, 燃協誌, 67, 764 (1988)

10) Takeda, S., Honma, S., Tazaki, Y., Yumiyama, M., Chiba, T. and Takezawa, N., J. Chem. Eng. Japan, 23, 396 (1990)

11) Adshiri, T. and Furusawa, T., Chem. Eng. Sci., 42, 1313 (1987)

12）武田詔平, 本間専治, 田崎米四郎, 弓山 翠, 石 栄煒, 千葉忠俊, 竹澤暢恒, 燃協誌, 69, 752 (1990)

13) Dutta, S., Wen, C.Y. and Belt, R.L., Ind. Eng. Chem. Proc. Des. Dev., 16, 20 (1977)

14）宝田恭之, 井田直幸, 日置明夫, 神原信志, 山本 美奈子，加藤邦夫，燃協誌，67, 1061 (1988)

15) Shemet, V.Zh., Pomytkin, A.P. and Neshpor, V. S., Carbon, 31, 1 (1993)

16) Radovic, L.R., Walker, P.L.Jr. and Jenkins, R. G., Fuel, 62, 849 (1983)

17) Causton, P. and McEnaey, B., Fuel, 64, 1447 (1985)

18) Kyoutani, T., Karasawa, S. and Tomita, A., Fuel, 65, 1466 (1986)

19）橋本健治, 三浦孝一，徐 継軍，燃協誌， 66,418 (1987) 


\title{
Pressurized Gasification of Entrained Coal Char from Entrained Bed Gasifier
}

\author{
Senji Honma ${ }^{* 1}$, Shohei TAKedA ${ }^{* 1}$, Kunihiro Kitano*1, Ryoichi YoshidA *1 \\ Shuntaro KOYAMA ${ }^{* 2}$ and Akio UEDA $* 3$ \\ $\left(\begin{array}{ll}* 1 & \text { Hokkaido National Industrial Research Institute } \\ * 2 & \text { Hitachi Ltd. Co. }\end{array}\right)$ \\ *3 Babkoch Hitachi Ltd. Co.
}

SYNOPSIS : - The reactivity of entrained coal char is an important issue for improving total efficiency of the entrained bed gasifier by recycling cyclone captured char. This study aims to elucidate the differences of reactivities among chars that have different heating history. Four kinds of coals were used for the experiments. Char samples were collected by cyclone in the 3 ton/day bench scale entrained bed gasifier. In addition, carbonized char samples were prepared in the batch reactor to compare with reactivities of entrained chars.

The differences of reactivities among char samples were successfully correlated with the difference of numbers of active site. The effects of pressure and temperature were also investigated. The dependency of reaction rate constants on pressure was proportional to $1 / 4$ power of total pressure at $1270 \mathrm{~K}$. The pressure dependence on reactivities was not observed under the conditions of pressure over $1.6 \mathrm{MPa}$ at the higher temperature as $1570 \mathrm{~K}$. This may be caused by the reaction limiting step change from reaction control to diffusion control.

The experimental results show that the entrained chars have the higher reactivities than carbonized char. This suggests that the entrained char recycle to the gasifier is beneficial to improve total efficiency of gasifier.

\section{Key Words}

Pressurized gasification, Coal char, Active site number, Reactivity 